Research Journal of Applied Sciences 7 (7): 349-353, 2012

ISSN: $1815-932 \mathrm{X}$

(C) Medwell Journals, 2012

\title{
Analysis of Heavy Metal Concentration in the Vicinity of a Land fill Site
}

\author{
${ }^{1}$ Zaini Sakawi, ${ }^{2}$ S.A. Sharifah Mastura, ${ }^{3}$ Mohd Rozaimi Ariffin, \\ ${ }^{3}$ Lukman Ismail and ${ }^{2}$ Othman Jaafar \\ ${ }^{1}$ Earth Observation Centre, Faculty of Social Sciences and Humanities, \\ UKM, Selangor, Malaysia \\ ${ }^{2}$ Institute of Climate Change, Universiti Kebangsaan Malaysia, Selangor, Malaysia \\ ${ }^{3}$ School of Social, Development and Environmental Studies, FSSK, UKM, Selangor, Malaysia
}

\begin{abstract}
Landfill site is the final destination in the cycle of waste generation. The landfill issues per its site, locality and alternative uses are the chronic issues commonly occurring at local, regional and global levels. Waste related pollution of the environment such as air (gas and odour), soil and underground water are perennial issues. Heavy metal contamination of the soil is a visible impact on the physical environment and human health. This study aims to analyses the concentration of heavy metal in the soil per the distance and depth of soil from the site of the landfill. The findings indicated that there were negative and positive relationship in the concentration of heavy metal per the distance and depth. Evidently factors like the type of soil, agricultural activities and rainfall did influence the concentration of heavy metal in the vicinity surrounding the landfill site.
\end{abstract}

$\underline{\text { Key words: Landfill site, heavy metals, waste management, land contaminated, leachate }}$

\section{INTRODUCTION}

Waste disposal issues are not just a local but also global. It is a cycle of continuing problem beginning with the generation of waste at its source until the final destination at the landfill. Government effort through it environmental agencies has not been very successful. The launches of national recycling programed in 1993 and 2002 have not been able to garner total involvement of all strata of the society (Sakawi, 2011). The effort to build an incinerator to resolve waste generation issues, particularly in urban ecosystem has met stiff resistance. Protests by local community to derail the building of incinerator has been a common phenomenon despite their awareness of worsening waste disposal issues (Sakawi, 2005, 2006). The community insensitiveness and rather uncharitable attitude of Not in My Back Yard (NIMBY) syndrome are factors contributing to the failure in the management of waste generation and disposal issues.

Pollution originating from the landfill is often attributed to the accumulation of untreated waste and leachate which seeped through the soil into the river nearby. This phenomenon is a direct cause of water pollution. Specific studies on waste management in developed and developing countries, for examples are Abert and Vamcil (1977), Anderson (1998), Bai and Sutanto (2002), Beigh et al. (2008) and Coskeran et al.
(2007). Those focusing on heavy metals were (Mico et al., 2007; Baker et al., 1994; Bradl, 2005; Emmanuel et al., 2005); forecast on concentration of heavy metals (Marjorie and Davis, 2007) heavy metals in aquatic ecosystem, agricultures and environment (Mokhtar et al., 2003) and landfill site locality (Sumiani et al., 2009). These studies essentially wanted to analyses the link between heavy metals with the environment and the focus often on the contamination of heavy metal in aquatic ecosystem. Nevertheless, there is a dearth of studies on the operations and management of landfill, its heavy metal concentration and environmental impact.

Management of contaminated soil around the landfill ought to be seen as a vital containment strategy for the its impact is not limited to the physical presence of heavy metal in soil but also damaging to underground water quality (Sakawi et al., 2011). Furthermore, inefficient management will adversely affected the well-being of local community and other habitats. Management of rehabilitation and redevelopment of contaminated land around the landfill for future use is also a chronic issue in Malaysia. There, is a dearth of studies to address this issue. Therefore a specific study need to be conducted to analyses the heavy metal contamination and its level of viscosity in the landfill area per the distance from the landfill and depth of the soil around its vicinity.

Corresponding Author: Zaini Sakawi, Earth Observation Centre, Faculty of Social Sciences and Humanities, UKM, Selangor, Malaysia 


\section{MATERIALS AND METHODS}

The soil analysis at the landfill involved 60 samples. Sampling stations were sited per four major wind directions: North, South, East and West. The samplings were done outwardly parallel from the landfill with marked distances of $10,20,30,40$ and $50 \mathrm{~m}$. Soil samples were taken using Auger instrument according to soil depth of 30,60 and $90 \mathrm{~cm}$, respectively. A total of $500 \mathrm{~g}$ sampling soil was taken from each sampling station.

The samples were dried in the laboratory for 3 days under $25^{\circ} \mathrm{C}$ in an aluminum alloway tray. Before the analysis was conducted, the soil sample was pounded to obtain a finer sample size $<2 \mathrm{~cm}$. Subsequently, the soil was shaken using Laboratory Test Sieve Model BS 410 with an opening size $63 \mu \mathrm{m}$. The purpose of the test was to obtain homogeny soil sample.

The soil heavy metal analysis was conducted according to a method used by EPA SW 846 Method 3050. Determination of heavy metal was done using the ICP-MS Method (Inductive Couple Photometer-Mass Spectroscopy). Only several types of dominant metals were selected for the study. Among them were $\mathrm{Cr}, \mathrm{Mn}, \mathrm{Fe}$, $\mathrm{Ni}, \mathrm{Cu}, \mathrm{Zn}, \mathrm{As}, \mathrm{Cd}$ and $\mathrm{Pb}$.

\section{RESULTS AND DISCUSSION}

Figure 1 shows the content of heavy metal around the vicinity of the landfill. The reading of the heavy metal were ranked as $\mathrm{Cd}>\mathrm{Fe}, \mathrm{Ni}>\mathrm{As}>\mathrm{Zn}>\mathrm{Mn}>\mathrm{Pb}>\mathrm{Cu}>\mathrm{Cr}$. The highest value for $\mathrm{Cd}$ was $282.8 \mathrm{mg} \mathrm{L}^{-1}$ followed by $\mathrm{Ni}$ and $\mathrm{Fe}$ at $41.72 \mathrm{mg} \mathrm{L}^{-1}$ and the lowest was for $\mathrm{Cr}$ at $6 \mathrm{mg} \mathrm{L}^{-1}$. The analysis indicated that the highest reading for heavy metals were for $\mathrm{Cd}, \mathrm{Pb}, \mathrm{Mn}$ and $\mathrm{Zn}$ in the Eastern side within a distance of $20 \mathrm{~km}$ and depth of $90 \mathrm{~cm}$ while for As, it was at $10 \mathrm{~m}$ with depth of $30 \mathrm{~cm}$ while for $\mathrm{Cu}$, it was at the depths of 50 and $90 \mathrm{~cm}$.

The highest soil content of heavy metal was attributed to the topology of the area being contaminated with leachate from the landfill within $10-20 \mathrm{~m}$ distance. The effect of the heavy metal viscosity was evident with some perished vegetation surrounding the sampling stations. In the North area, the heavy metal detected were $\mathrm{Fe}$ and $\mathrm{Ni}$,

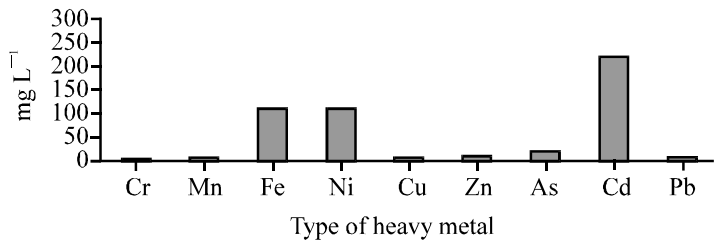

Fig. 1: The concentration of heavy metals from the landfill at the distance of $30 \mathrm{~m}$ from the landfill and depth of $60 \mathrm{~cm}$ from the surface of the soil. The analysis showed that the viscosity of the heavy metal found high in Southern area was that of $\mathrm{Cr}$ within a sampling distance of $50 \mathrm{~m}$ from the landfill and at $30 \mathrm{~cm}$ depth.

The findings on the viscosity of the heavy metal for all selected parameters were found to be higher compared to a study by Umi Kalsom with the exception of $\mathrm{Fe}$ and $\mathrm{Zn}$. This study has revealed the evidence of $\mathrm{Cd}$ contamination in high concentration around the sampling stations.

The results of the analysis showed that the rate of contamination per the mean of standard deviation for $\mathrm{Cr}$, $\mathrm{Mn}, \mathrm{Fe}, \mathrm{Ni}, \mathrm{Cu}, \mathrm{Zn}, \mathrm{As}, \mathrm{Cd}$ and $\mathrm{Pb}$ in the sediments was dominated by $\mathrm{Cd}$ and subsequently by $\mathrm{Cd}>\mathrm{Ni}>\mathrm{As}>\mathrm{Cr}$ $>\mathrm{Pb}>\mathrm{Mn}>\mathrm{Cu}>\mathrm{Zn}>\mathrm{Fe}$. The deviation mean is content viscosity of heavy metal based on standard of safety level for soil. The highest level of contamination was that of $\mathrm{Cd}$ at $18.19 \mathrm{~mL} \mathrm{~g}^{-1}$ exceeding the standard safety level. This was followed by $\mathrm{Ni}$ with a reading of $4.24 \mathrm{mg} \mathrm{L}^{-1}$ while the lowest was $\mathrm{Fe}$ and $\mathrm{Ni}$ both at $-0.21 \mathrm{mg} \mathrm{L}^{-1}$. The increase in $\mathrm{Cd}$ and $\mathrm{Pb}$ contamination level was attributed to the intense usage of prostate in the area of the landfill. The increase in prostate content in the soil was due to the use of fertilizer at the landfill (Fig. 2).

Analysis of the correlation of the viscosity of the heavy metals per depth and distance of the samplings indicated causal linkage between these variables. The results have shown high correlations and significance occurring in the North and West areas. This phenomenon evidently showed the surreptious movement of heavy metals from the landfill to its surrounding areas. Table 1 shows the existence of negative relationship towards the North and West areas at the depth of $90 \mathrm{~cm}$ while there was positive relationship at sampling stations in the west at the depth of $60 \mathrm{~cm}$.

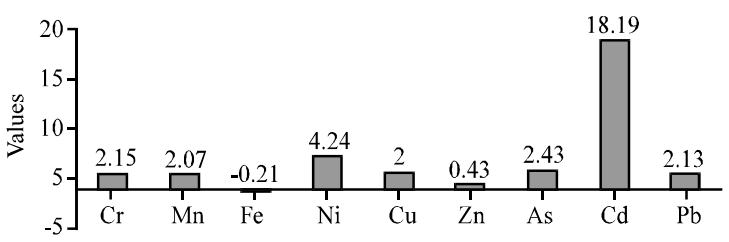

Fig. 2: Standard deviation of contaminated rate

Table 1: Correlation of heavy metal concentrations in soils according to depth and distance

\begin{tabular}{lcccc}
\hline Direction & Depth & Type of metal & Correlation & Significant level \\
\hline North & 90 & CD & -918.000 & 0.080 \\
West & 60 & CR & 0.971 & 0.006 \\
West & 90 & CU & -0.904 & 0.035 \\
\hline
\end{tabular}


Figure 3 shows the concentration of heavy metals per sampling distance from the landfill for Northern direction. The findings indicated that there exists negative relationship for $\mathrm{Cd}$ from the landfill area towards the North. The highest concentration of Cd was detected at sampling station about $10 \mathrm{~m}$ from the landfill with $26.8 \mathrm{mg} \mathrm{L}^{-1}$. While sampling station at $30 \mathrm{~m}$, showed slight increase compared to other stations with $16.8 \mathrm{mg} \mathrm{L}^{-1}$. Nevertheless, the decrease of $\mathrm{Cd}$ concentration was significantly more distinctive as distance increase further North from the landfill.

Figure 4 shows the results of the analysis of the standard deviation of heavy metal per the depth of $60-90 \mathrm{~cm}$, especially for sampling station facing the North side of the landfill. The presence of contaminated elements of $\mathrm{Fe}$ and $\mathrm{Mn}$ are very low at distance of $10-50 \mathrm{~m}$ from landfill. A major source of the heavy metal contamination was the landfill. Nevertheless, other factors influencing the concentration of heavy metal, particularly $\mathrm{Pb}$ and $\mathrm{As}$ was the phostate fertilizer used by the farmers. The mean of standard deviation for the heavy metal concentration was at 2 and $1 \mathrm{mg} \mathrm{L}^{-1}$ at a distance of $10 \mathrm{~m}$; increase in contamination was in parallel distance of $20-50 \mathrm{~km}$ from the landfill. For $\mathrm{Ni}, \mathrm{Cr}$ and $\mathrm{Cu}$, the levels

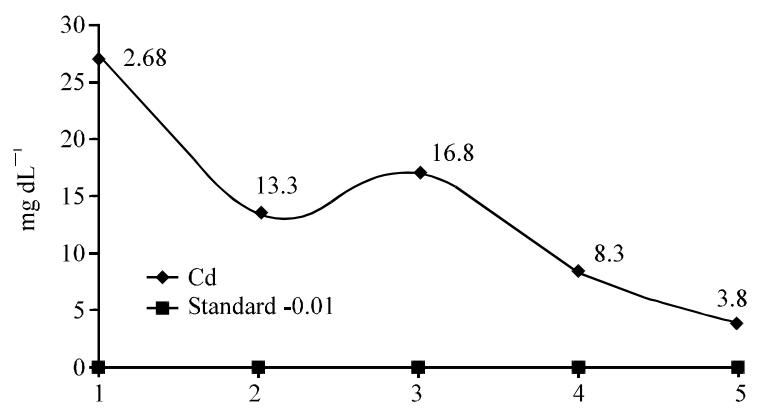

Fig. 3: Sample point with $90 \mathrm{~cm}$ (depth) and $50 \mathrm{~m}$ (distance) from landfill at North site

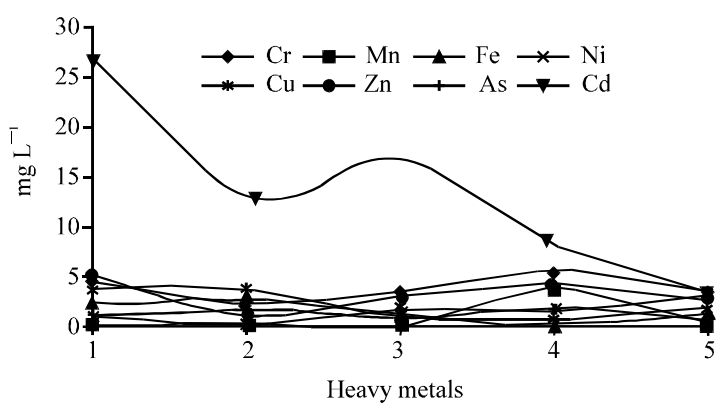

Fig. 4: The standard deviation of heavy metal with $60-90 \mathrm{~cm}$ depth at North site of contamination were still low at 10-50 m. Overall, there existed an increase in concentration compared to a study by Umi Kalsom. There was positive relationship for $\mathrm{Zn}$ and $\mathrm{Cd}$ where high content of $\mathrm{Zn}$ influenced the high content of $\mathrm{Cd}$ for $\mathrm{Zn}$ reduced the capacity to absorb $\mathrm{Cd}$ in the soil by the plants.

Figure 5 shows the concentration of $\mathrm{Cu}$ at the depth of $90 \mathrm{~cm}$ and a distance of $50 \mathrm{~m}$ from the landfill from the west area samplings. Negative relationship also occurred on the west side of the landfill. Overall, the $\mathrm{Cu}$ concentration at $10 \mathrm{~m}$ was $3.7 \mathrm{mg} \mathrm{L}^{-1}$, increased a little at $20 \mathrm{~m}$ to about $0.5 \mathrm{mg} \mathrm{L}^{-1}$. Henceforth this metal concentration gradually decreased with increasing distance from the landfill.

Figure 6 shows a negative relationship between content of $\mathrm{Cd}$ and sandy soil. The content of $\mathrm{Cd}$ was low at the depth of $90 \mathrm{~cm}$ with standard deviation mean of $6.29,4.19$ and $0.89 \mathrm{mg} \mathrm{L}^{-1}$ over a distance of $10-30 \mathrm{~m}$ of sandy soil. Large sandy sediment in the soil induced low absorption rate of heavy metal. An increase of reading for $\mathrm{Cd}$ at the distance of $40-50 \mathrm{~m}$ was due to loamy soil which was able to hold heavy metal in the ground. Even though there was an increase in Cd element at the surface of the oil, this was due to the emission of

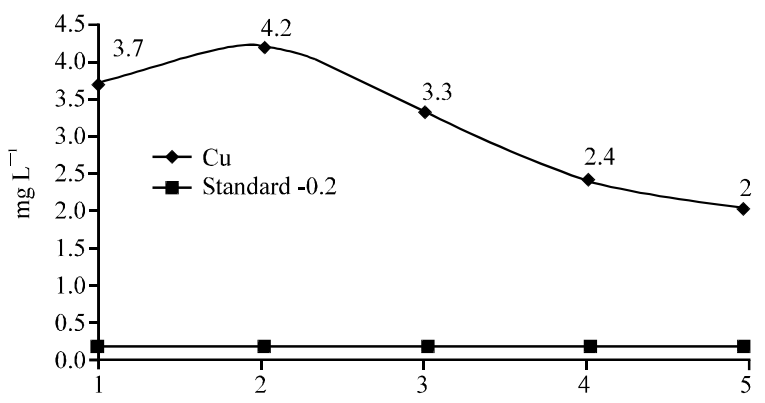

Fig. 5: Concentration of $\mathrm{Cu}$ with $90 \mathrm{~cm}$ (depth) and $50 \mathrm{~m}$ (distance) from landfill at West site

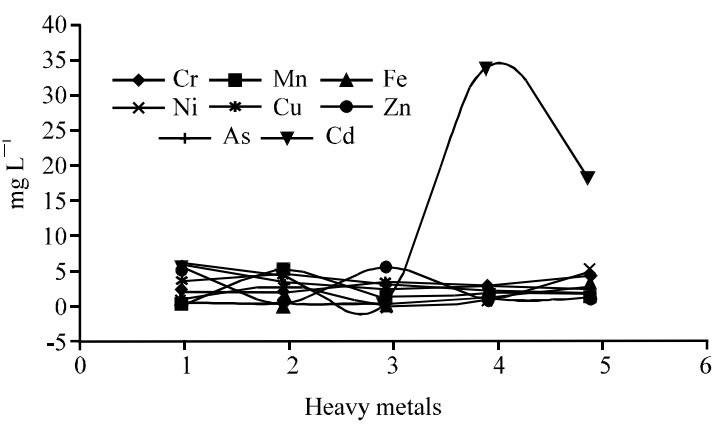

Fig. 6: Standard deviation of heavy metal with $60-90 \mathrm{~cm}$ (depth) at West site 
vehicular smoke, for within a distance of $10-30 \mathrm{~m}$ was a road way for lorries transporting sands in the area. The reading for $\mathrm{Fe}$ within the area of the study showed a low level contamination.

There was a positive relationship at the depth of $60 \mathrm{~cm}$ in the western direction of the landfill of Ampar Tenang which showed an increasing content of $\mathrm{Cr}$, in tandem with the distance (Fig. 7). The concentration of the heavy metal for $10 \mathrm{~m}$ distance was $0.9 \mathrm{mg} \mathrm{L}^{-1}$. While the concentration per increasing distance from the landfill also showed high concentration at $1.5 \mathrm{mg} \mathrm{L}^{-1}(20 \mathrm{~m})$, $2.5 \mathrm{mg} \mathrm{L}^{-1}(30 \mathrm{~m}) 2.9 \mathrm{mg} \mathrm{L}^{-1}(40 \mathrm{~m})$ and $3.1 \mathrm{mg} \mathrm{L}^{-1}(50 \mathrm{~m})$. The increase of $\mathrm{Cr}$ in the West site at the depth of $60 \mathrm{~cm}$ may be due to the high sand content in the soil. This phenomenon was caused by the high sand concentration in $\mathrm{Fe}$, turning it into an absorption agent for $\mathrm{Cr}$.

The concentration of $\mathrm{Cr}$ was almost the same for every depth level between $0-30,30-60$ and $60-90 \mathrm{~cm}$ to the West. A decrease occurred for $\mathrm{Cr}$ at the distance of $30 \mathrm{~m}$ with $-0.01 \mathrm{mg} \mathrm{L}^{-1}$ and then an increase to $21.39 \mathrm{mg} \mathrm{L}^{-1}$ and $41.59 \mathrm{mg} \mathrm{L}^{-1}$ at distance of $40 \mathrm{~m}$ and $50 \mathrm{~m}$ (Fig. 8). The increase occurred due to the loamy soil at the site of sampling station; for loam or clay has high capacity to hold heavy metal in the soil. Evidently, the use of phosphate fertilizer by farmers also contributed to the concentration of heavy metals in the western direction.

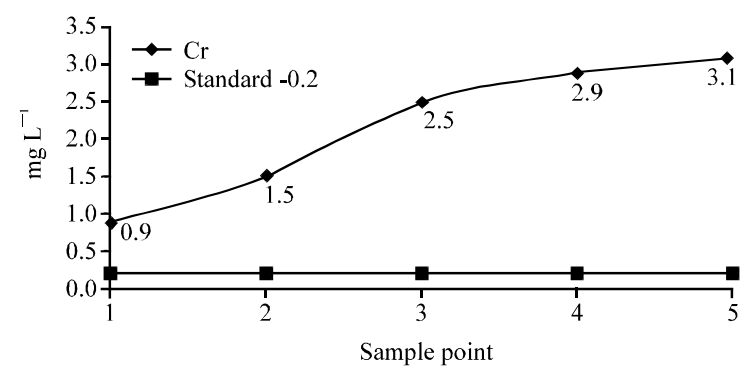

Fig. 7: Sample point at $60 \mathrm{~cm}$ (depth) and $50 \mathrm{~m}$ (distance) at West site

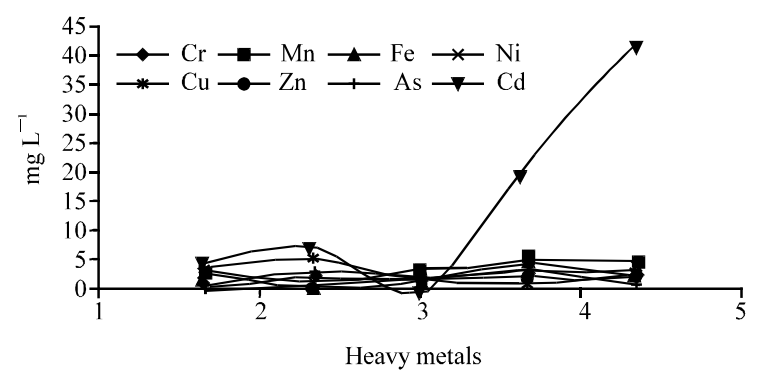

Fig. 8: Standard deviant of heavy metal (Cr) with $30-60 \mathrm{~cm}$ (depth) at West site
While the concentration of $\mathrm{Zn}$ and $\mathrm{Fe}$ contamination was low (Fig. 8). The highest mean of the standard deviation obtained for both heavy metals were -0.2 for $\mathrm{Fe}$ and -0.1 for $\mathrm{Zn}$. The same phenomenon was identified per standard deviation for $\mathrm{Mn}, \mathrm{Ni}$ and $\mathrm{Cu}$ and $\mathrm{As}$ which showed low deviation. Even though there were irregular increase and decrease between the heavy metals within distance of $10-50 \mathrm{~m}$, changes in standard deviation was nevertheless low (Fig. 8).

\section{CONCLUSION}

The final analysis indicated that the concentration of heavy metal contamination in the area of study was in the rank order as $\mathrm{Cd}>\mathrm{Ni}>\mathrm{As}>\mathrm{Cr}>\mathrm{Pb}>\mathrm{Mn}>\mathrm{Cu}>\mathrm{Zn}>\mathrm{Fe}$. The highest concentration of heavy metal in the soil detected around the landfill was $\mathrm{Cd}$ with the concentration of $282 \mathrm{mg} \mathrm{L}^{-1}$ at the depth of $30 \mathrm{~cm}$ and sampling distance of $30 \mathrm{~m}$. The direction of the sampling for $\mathrm{Cd}$ concentration was to the west side of the landfill.

While higher concentration of $\mathrm{Fe}$ and Ni were located on the North side. Lab analysis found that $141.7 \mathrm{~m} \mathrm{~L}^{-1}$ concentration on this North side was detected at the depth of $60 \mathrm{~cm}$ and $30 \mathrm{~m}$ distance from the landfill.

Even though there were indications of high concentration of heavy metal per the distance and soil depth at the sampling stations, it did not indicate serious air pollution. The collective concentration obtained from all stations indicated that the levels of contamination were still low and rather irregular.

Correlation analysis on the concentration of heavy metals did indicate negative and positive relationships between distance and depth at study site. The negative relationships existed due to increasing distance from the landfill whereby the concentration of heavy metal decreased accordingly. This negative or irregular relationship was detected at sampling stations to the north and west sides of the landfill at the depth of $90 \mathrm{~cm}$. This condition may occur due to soil factor which contained water that affect the concentration of heavy metal as the distance increased from the landfill. The effect of underground water had reduced the concentration of heavy metal as it was carried farther from the landfill.

For positive relationships, the correlation only occurred at sampling station to the West but at the depth of $60 \mathrm{~cm}$ from the surface. Figure 7 shows evident of positive relationship between concentration of heavy metals and distance from the landfill factor. This phenomenon obviously point to the presence of sandy soil in the sampling areas which affected the concentration of heavy metals, particularly Cr. The 
presence of higher concentration of $\mathrm{Fe}$ in sandy soil forms an absorption agent for $\mathrm{Cr}$ which intensifies its concentration on the site.

Generally, this study has revealed that concentration of heavy metals in the soil in the vicinity of the landfill whether in the North, South, West and East directions did not indicate an alarmingly high increase in concentration of heavy metals. In fact, analysis on the concentration did indicate other contributory factors such as sandy soil, agricultural activities and animal rearing. The soil depth factor also did not indicate obvious impact on an increase in concentration of heavy metal. Even for sampling stations within the same direction, the variation in depth showed similar trends of heavy metal concentration. Therefore in addition to the intrinsic contaminating characteristics of the heavy metals, other environmental factors such as types of soil and running water also directly influenced the increase and reduction of concentration of heavy metals in the vicinity of the landfill surroundings.

\section{ACKNOWLEDGEMENT}

Researchers wish to gratefully acknowledgement financial support for this research by Ministry of Science, Environmental and Technology Malaysia (MOSTI), Faculty of Social Sciences and Humanities, CRIM and Universiti Kebangsaan Malaysia (UKM) under grant code UKM-SK-07-FRGS0039-2009.

\section{REFERENCES}

Abert, J.G. and R.M. Vamcil, 1977. A graphical approach to determine the economics of recovering resources from municipal solid waste. Conserv. Recycl., 1: 299-314.

Anderson, E.G., 1998. Privatising management of solid waste in developing countries, the Malaysian experience. Proceedings of the Roundtable on Urban Solid Waste Management, September 27-28, 1998, Bahia, Brazil.

Bai, R. and M. Sutanto, 2002. The practice and challenges of solid waste management in Singapore. Waste Manage., 22: 557-567.

Baker, A.J.M., S.P. McGrath, C.M.D. Sidoli and R.D. Reeves, 1994. The possibility of in situ heavy metal decontamination of polluted soils using crops of metal-accumulating plants. Resour. Conserv. Recycl., 11: 41-49.
Beigh, P., S. Lebersorger and S. Salhofer, 2008. Modelling municipal solid waste generation: A review. Waste Manage., 28: 200-214.

Bradl, H., 2005. Heavy Metal in the Environment: Origin, Interaction and Remediation. 1st Edn., Elsevier Academic Press, Amsterdam, The Netherlands, ISBN-13: 978-0120883813, Pages: 282.

Coskeran, T., S. Smith and P. Philips, 2007. An economic modelling approach to the design and delivery of sustainable waste minimisation clubs: Prospects in the new policy framework. Resour. Conserv. Recycl., 50: $398-414$.

Emmanuel, D., V. Virginie and S.M. Herve, 2005. Heavy Metal Content in Soils of Reunion (Indian Ocean). Elsevier Academic Press, Heidelberg, Germany.

Marjorie, A.C. and H.T. Davis, 2007. Use of a general toxicity test to predict heavy metal concentrations in residential soils. Chemosphere, 67: 1043-1049.

Mico, C., M. Peris, L. Monica and J. Sanchez, 2007. Baseline values for heavy metals in agricultural soils in a European Mediterranean region. Sci. Total Environ., 378: 13-17.

Mokhtar, M., M.T. Latif and L.Y. Heng, 2003. Water Chemistry. Utusan Publisher, Kuala Lumpur, Malaysia.

Sakawi, Z., 2005. The implementation of Environmental Auditing for efficient waste management systems in Malaysia. Sarawak Dev. J., 1: 1-10.

Sakawi, Z., 2006. Barriers to site selection for an incinerator (waste-to-energy) in Malaysia. Proceedings of the International Conference for Waste 2006: Sustainable Waste and Resource Management, September 12-14, 2006, Warwickshire, UK., pp: 697-706.

Sakawi, Z., 2011. Municipal solid waste management in Malaysia: Solution for sustainable waste management. J. Applied Sci. Environ. Sanitation, 6: 29-38.

Sakawi, Z., S. Mastura and S.A.O. Jaafar, 2011. The impact of open landfill operation on the concentration of heavy metals in the soil of its proximate environment. Res. J. Applied Sci., 6: 439-442.

Sumiani, Y., C.C. Onn, M.A. Mohd Din and W.Z. Wan Jaafar, 2009. Environmental planning strategies for optimum solid waste landfill siting. Sains Malaysiana, 38: $457-462$. 